\title{
(НЕ)ПОЗНАТИ ПРЕПИС ДУШАНОВА ЗАКОНИКА У МУЗЕЈУ СРПСКЕ ПРАВОСЛАВНЕ ЦРКВЕ У БЕОГРАДУ*
}

САЖЕТАК: У раду се представља незапажени препис Душанова законодавства из средине XVIII века, што га је пронашао Тихомир Остојић у библиотеци манастира Хопово 1906. године прикупљајући грађу за своју студију о боравку Доситеја Обрадовића у том манастиру. То је кодекс од преко 500 листова, разнородне садржине, на чијем крају су преписани састави млађе редакције Душанова законодавства - Закон Константина Јустинијана и Душанов законик. Преписао га је хоповски јеромонах Спиридон Јовановић око 1750. године. Рукопис смо назвали Хоповски, због писара и места чувања до почетка Другог светског рата. Данас се налази у Музеју Српске православне цркве, у Збирци Радослава Грујића, под бројем 127. Поређењем са осталим рукописима млађе редакције Душанова законодавства установили смо да је непосредни предложак са којег је Спиридон Хоповац преписао текстове Душанова законодавства Сандићев (Стратимировићев) рукопис, настао око 1724. Хоповски препис не доноси садржински ништа ново, али је једини познати пример да текстови Душанова законодавства нису примарни или једини у рукопису. Друга особена одлика овог преписа јесте сразмерно велик удео народног говора и иновираних језичких облика.

КљУЧНЕ РЕЧИ: Душанов законик, Закон Константина Јустинијана, манастир Хопово, Спиридон Јовановић, Сандићев препис Душанова законодавства, Тихомир Остојић, Музеј СПЦ

\footnotetext{
* Чланак садржи део резултата насталих на пројекту „Српско средњовековно друштво у писаним изворима” (бр. 177025), који подржава Министарство просвете, науке и технолошког развоја Републике Србије.
} 
Састављајући 1959. године попис тада познатих преписа Душанова законика, Никола Радојчић, један од наших најбољих познавалаца тог правног споменика, могао их је набројати 24, не рачунајући Београдски (Руднички), изгорео у немачком бомбардовању Народне библиотеке у Београду. Тај попис, с основним подацима о рукописима, објављен је наредне године у оквиру уводне студије уз издање и превод Душанова законика. ${ }^{1}$ Пошто се, на срећу, текст Душанова законика из изгорелог Београдског рукописа сачувао у препису Јанка Шафарика, од времена Радојчићева издања може се говорити о 25 познатих и доступних преписа. У наредних шест деценија тај се број прећутно усталио као коначан и безмало сви прегледи рукописне традиције Душанова законика наводе 25 преписа, насталих од краја XIV до средине XIX века. ${ }^{2}$ Тек последњих година њима је с правом, и с неоправданим задоцњењем, прикључен румунски превод Душанова законика из 1776. године, ${ }^{3}$ иако познат, описиван и испитиван у румунској историографији готово читаво претходно столеће. ${ }^{4}$

Проучаваоцима Душанова законика вазда су распаљивали машту наговештаји постојања нових, непознатих преписа, али такви трагови нису до сада довели до нових открића - водили су или у погрешном смеру или ка већ познатим рукописима. Још је Новаковић, у издању Законика из 1898, навео податак за који ни сам није знао откуда му, да је наводно 1853. у скривници манастира Тавна код Бијељине виђен примерак Законика. ${ }^{5}$ Вођен тим трагом, Александар Соловјев два пута је походио манастир, 1927. и 1948, али није нашао ништа осим уверавања да су Турци до темеља спалили Тавну 1875. и да у манастиру не постоји скривница. 6 У приказу Новаковићева издања Законика из 1898, Тихомир Ђорђевић пренео је усмено саопштење проте Стевана Димитријевића да је у Библиотеци Св. Синода у Санкт Петербургу видео рукопис Законика. ${ }^{7}$ Соловјев је следио и тај траг, али је од

1 Законик изара Се̄ефана Дущиана 1349 и 1354, прир. Н. Радојчић, Београд 1960, 14-24.

2 Наводим само неколико најутицајнијих публикација: М. Бартош, „Зборник рукописа Законика цара Стефана Душана (1349. и 1354. године). Уводне напомене”, Законик ияара Сйефана Дущана, књ. I, Сйрущки и Айонски рукойис, Одељење друштвених наука САНУ, Извори српског права IV, Београд 1975, 2, 10-15; А. Соловјев, Законик иара Сӣефана Дущиана 1349. u 1354. ìoguне, Одељење друштвених наука САНУ, Извори српског права VI, Београд 1980, 37-99 (из неког разлога није навео Карловачки рукопис, иако на почетку излагања говори о 25 преписа); Дущцанов законик, прир. Б. Марковић, Стара српска књижевност у 24 књиге, Београд 1986, 101-108; Г. Радојчић-Костић, Библиоірафија о законоgавстиву иара Сӣефана Дущиана, Одељење друштвених наука САНУ, Извори српског права XII, Београд 2006, 13-22.

3 Прва о њему доноси податке Биљана Марковић 2007. године (Јустиинијанов закон. Средњовековна визанӣијско-срйска йравна комйилачија, прир. Б. Марковић, Одељење друштвених наука САНУ, Извори српског права XV, Београд 2007, 7, 47 нап. 36). Упор. и попис рукописа Душанова законика у моме издању: Дущанов законик, прир. Ђ. Бубало, Београд 2010, 25-63.

4 Ливију Темпеа продао га је 24. октобра 1905. Библиотеци Румунске академије, а први је о рукопису писао Јон Перец 1928. године (I. Peretz, Curs de istoria dreptului romăn, II-2, București 1928, 14-28).

5 Законик Сёефана Дущшана иара срӣскої 1349. и 1354, прир. Ст. Новаковић, Београд 1898, LXXXVII.

6 А. Соловјев, Законик, 101.

7 Т. Ђорђевић, „Приказ Законика Ст. Душана од Стојана Новаковића”, Босанска вила, 23-24 (1899) 359 . 
петербуршког професора Владимира Николајевича Бенешевича добио уверавања да је реч о рукопису Синтагме Матије Властара. ${ }^{8}$

Никола Радојчић саопштио је 1960. податак из једног писма упућеног Алекси Ивићу 1935. о рукопису Душанова законика који се налазио у оставштини књижевника Светислава Вуловића, питајући се: „Где је тај рукопис?”.9 Није ни слутио да је реч о Карловачком рукопису из 1764, који је управо он представио научној јавности 1951, ${ }^{10}$ након што га је Народна библиотека Србије откупила од Српске књижевне задруге. ${ }^{11}$ Загонетку Вуловићевог рукописа успео је да разреши Боривоје Маринковић, готово пола столећа доцније. ${ }^{12} \mathrm{Oн} \mathrm{је} \mathrm{пронашао} \mathrm{податке} \mathrm{неопходне} \mathrm{за} \mathrm{поистовећивање} \mathrm{Вуловиће-}$ вог и Карловачког рукописа у писму Вуловића Илариону Руварцу, написаном почетком 1888. године, а објављеном у Бранковом колу још 1909.13 Тим писмом власник је обавестио Руварца о старој књизи коју је набавио и описао ју је с појединостима које не остављају места сумњи да је реч управо о Карловачком рукопису. ${ }^{14}$ У литератури, разуме се, има још путоказа ка наводно непознатим рукописима, које овде нећу посебно наводити, 15 али све их обједињују, и поред тога што до сада нису довели до нових открића, охрабрујуће речи Николе Радојчића, „да у тами заборава почива још рукописа Законика” и да се „на списак рукописа Душанова законодавства не сме стављати завршна тачка". 16

И заиста, сада можемо рећи да је његов оптимизам био оправдан. Заправо, потрага за новим преписима било ког састава старе писмености или откривање потпуно непознатих дела не сме почивати само на магловитим

8 А. Соловјев, Законоgавстиво Сйефана Душана иара Срба и Грка, Скопље 1928, 36; Београд 19982, 344-345; В. Н. Бенешевич, „Два списка славянского перевода Синтагмы Матфея Властаря хранящиеся в СПб. Синодальной библиотеке", Известия Отделения русского языка и словесности Императорской акаgемии наук, том VI, кн. 4 (1901) 150-174. Рукопис се данас чува у Руском државном историјском архиву: Российский государственный исторический архив, Санкт-Петербург, Синодальная библиотека, № 302 (V. Alexandrov, The Syntagma of Matthew Blastares: The Destiny of a Byzantine Legal Code among the Orthodox Slavs and Romanians 14-17 Centuries. Forschungen zur byzantinischen Rechtgeschichte, Bd. 29, Frankfurt am Main 2012, 190).

${ }^{9}$ Н. Радојчић, Законик, 24.

${ }^{10}$ Н. Радојчић, „Карловачки рукопис Јустинијанова закона и Душанова законика”,

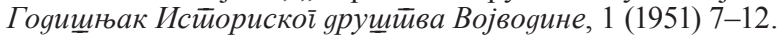

${ }^{11}$ О рукопису вид.: Ђ. Бубало, „Историја и историографија рукописа”, Законик иара

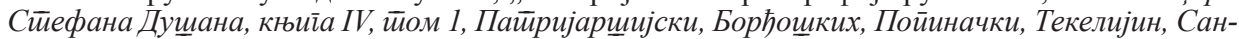
gићев, Ковиљски, Беоіраяски, Режевићки, Карловачки, Врщачки, Грбаљски, Бойищићев и Јайuћев рукойис, ур. К. Чавошки и Ђ. Бубало, САНУ, Одељење друштвених наука, Извори српског права IV, Београд 2015, 50-51.

12 Б. Маринковић, Скривени свет̄ Влаяимира Ћоровића, Билећа-Гацко 2006, 539-542.

13 Д. Руварац, „Писма Светислава Вуловића Ил. Руварцу”, Бранково коло, год. XV, св. 28 (1909) 445a.

14 Невоља је што је такво откриће саопштено тамо где би га мало ко очекивао - у публикацији о намераваним, необјављеним или уништеним радовима Владимира Ћоровића, за којег је познато да се, и поред свестраног научног интересовања, није посебно бавио Душановим законодавством. Из те перспективе посматрано, има неумољиве симболике у почетним речима наслова Маринковићеве књиге - „Скривени свет”.

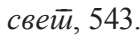

${ }^{15}$ Н. Радојчић, Законик, 24; А. Соловјев, Законик, 99-102; Б. Маринковић, Скривени

${ }^{16}$ Н. Радојчић, нав. местио. 
наговештајима и несигурним траговима, што се по чувењу или предању, без материјалних доказа, размењују међу стручњацима и лаицима. Неопходно је систематско истраживање рукописних збирки, од којих већина оних у којима се чува и српско рукописно наслеђе још није стручно и детаљно археографски описана, често имају само инвентаре или су описи сумарни, застарели и непотпуни. Штавише, и у случајевима када располажемо информативним средствима о рукописним збиркама, нису тако ретке омашке, погрешне атрибуције и идентификације. ${ }^{17}$

Године 2017, после деценија рада и одлагања, објављен је први том археографског описа збирке рукописа Радослава Грујића, која се чува у Музеју Српске православне цркве у Београду. ${ }^{18}$ Пажљиво прегледајући садржину појединих рукописа, према оригиналним насловима састава, пажњу ми је привукао зборник веома разноврсне садржине, заведен у збирци под бројем 127, написан на преко хиљаду страна средином XVIII века. На самом крају кодекса, на листовима 526-548, преписана су два састава чији су наслови одговарали онима који чине млађу редакцију Душанова законодавства - Закон Константина Јустинијана и Душанов законик. ${ }^{19}$ Љубазним посредовањем господина Мирослава Лазића, археографа у Одељењу за археографију Народне библиотеке Србије, и предусретљивошћу и разумевањем ђакона Владимира Радовановића, управника Музеја Српске православне цркве, добио сам прилику да прегледам рукопис и уверим се да је заиста реч о препису млађе редакције Душанова законодавства. Сада можемо са сигурношћу говорити о 27 познатих преписа Душанова законика, а можемо му без тешкоћа наденути и име - ХОПОВСКИ - јер га је, како сведоче записи писара и читалаца, преписао један хоповски пострижник и у манастиру Хопово чувао се најкасније до 1941. године.

Овај препис не помиње се нигде у обимној литератури о Душанову законодавном раду, нема га ни у једном попису преписа Душанова законика, 20 а судећи према подацима у публикованом опису Грујићеве збирке, о рукопису у којем је преписан нема ни литературе. Све то навело ме је на помисао да је реч о потпуно непознатом рукопису и препису Душанова законодавства. Међутим, већ после првих корака у потрази за литературом о писару и месту чувања рукописа и о делима која су у њему преписана ${ }^{21}$ постало је јасно да је лаконска тврдња из описа рукописа - „Литературе нема” - далеко од истине. Штавише, показало се да ни препис Душанова законика у њему није

17 Из свога искуства могу навести пример погрешне идентификације рукописа бр. 1 из збирке саборне цркве Св. Николе у Вршцу, који је забележен међу преписима Скраћене синтагме Матије Властара у незастаривом и много коришћеном приручнику Димитрија Богдановића, Инвенӣар ћирилских рукойиса у Jуйославији (XI-XVII век), САНУ, Београд 1982 , бр. 1430. Љубазношћу проте Огњена Вељанчића, старешине храма, добио сам рукопис на увид и уверио се да је реч о препису епитимијног номоканона, тзв. Псеудо-Зонаре.

18 В. Мошин, Љ. Васиљев, Д. Богдановић, М. Гроздановић-Пајић, Рукойиси Музеја Срйске йравославне иркве: Збирка Раgослава М. Грујића, I-1, Београд 2017.

19 Исто, 193-197.

20 Вид. нап. 2.

21 Да поменем само: извод из Хроника Ђорђа Бранковића, Еӣuӣом и Пройеgија Дионисија Новаковића, Кайихизис Василија Крижановског, одломци из историје Цезара Баронија,

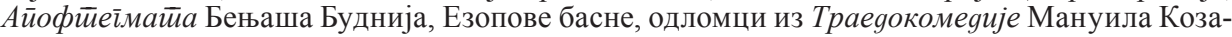
чинског, привилегије Српске цркве у Хабзбуршкој монархији, српски Хронограф итд. 
био остао незапажен. Стога се може рећи да рукопис бр. 127 Грујићеве збирке ипак није почивао у тами заборава, како се начелно био изразио Никола Радојчић, него је чудним стицајем околности све до данашњих дана измицао пажњи проучавалаца Душанова законодавства. Из те перспективе посматрано - сада је поново откривен!

Према мојим сазнањима, рукопис је у манастиру Хопово пронашао Тихомир Остојић 1906. године, прикупљајући грађу за студију о манастирским годинама Доситеја Обрадовића, ${ }^{22}$ и први га је и једини детаљно проучио. Остојић је настојао да, у мери у којој су то допуштали извори, пренесе читаоцу атмосферу у манастиру Хопово почетком друге половине XVIII века, свакодневицу манастирског живота и збивања која су је реметила. Нарочито се старао да проучи Доситејево духовно сазревање у манастиру, кроз утицаје игумана и братије, као и књига које су му у манастирској библиотеци биле доступне. Ти ће се утицаји одразити на његово потоње деловање и стваралаштво, те је Остојић покушао да утврди којим је делима Доситеј напајао своју жеђ за знањем. Из извештаја о визитацији манастира 1753. године могао је с великом вероватноћом реконструисати фондове манастирске и личних монашких библиотека, тј. оно што је Доситеју било на располагању за читање, а са сигурношћу је могао утврдити бар део литературе која је кроз његове руке прошла на основу Доситејевих сећања и његових записа на самим књигама. Управо ово последње дало је Остојићу повода да се детаљно позабави зборником у којем је било преписано и Душаново законодавство, јер је на подставном листу предње корице Доситеј оставио белешку:

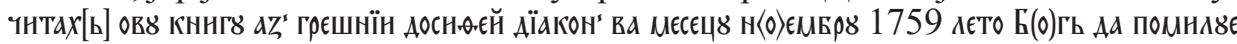
пнсавшаго юо н менє нєАостоннаго. ${ }^{23}$ Пошто је у истраживањима користио богату архивску грађу из хоповског архива, Остојић је успео, поређењем графије рукописа и манастирских протокола, да идентификује писара - хоповског јеромонаха Спиридона Јовановића - и задужи нас сразмерним богатством биографских података о њему, о чему ће доцније бити више речи.

Остојић је своју обимну студију објавио 1907. г. у издању Матице српске. У поглављу о Доситејевој лектири он је у појединостима описао садржину Сӣирияонова зборника, како га је именовао, што је остао његов уобичајен назив у литератури. ${ }^{24}$ На крају описа саопштени су и подаци о Душанову законодавству: „На крају Зборника уписао је Спиридон Законик цара Јустинијана и цара Душана. Текст овог преписа се слаже са млађим рукописима ових законика којих је репрезентант т. зв. Софиски препис". У напомени се позива на издања Новаковића из 1898. и Флоринскога из 1888, а потом даје кратка запажања о сличностима и разликама у обиму и структури у односу на Софијски и указује на куриозитет Спиридонова преписа који је средњовековни појам себар, разумео као серб, тј. Србин. ${ }^{25}$ Из овога кратког осврта

22 Оставио је датирани потпис на предњој страни листа 509.

23 Збирка Раgослава М. Грујића, 196. Запис је први издао Љ. Стојановић, Сйари срӣски зайиси и найиичси, II, Београд 1903, бр. 3150.

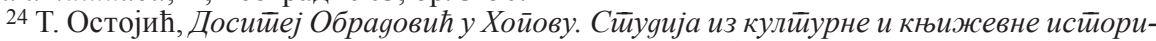
je, Књиге Матице српске бр. 19 и 20, Нови Сад 1907, 2002², 359-366; записе на рукопису издао је на стр. 377, укључујући и онај Доситејев (вид. претходну нап.).

25 Исто, 366 нап. 51. 
види се да је Остојић недвосмислено препознао текст млађе редакције Душанова законодавства и није оставио места сумњи да се ради о новом препису. 26

Остојић је дао да се преведе на немачки скраћена верзија његовог дела о Доситеју, на Јагићев подстицај пријавио ју је као докторску дисертацију, одбранио на Бечком универзитету исте године, а објавио 1909. у Јагићеву Архиву за словенску филолоїиј. И у тој скраћеној верзији оставио је места за детаљан опис Сйupugонова зборника и откриће преписа Душанова законодавства: „Am Ende der Handschrift ist das Gesetzbuch des Kaisers Justinian und des Zaren Dušan eingetragen. Der Text dieser Abschrift stimnat mit den jüngeren Handschriften dieses Kodex überein, deren Repräsentant die sog. Sofiaer Abschrift ist". ${ }^{27}$

Међу проучаваоцима Душанова законодавства ове вести прошле су незапажено, а тако је било и с новинском цртицом која је 1954, у раздобљу када је због обележавања шесте стогодишњице доношења Законика цара Душана било повећано интересовање за њега, објављена у дневном листу Политика. ${ }^{28}$ У непотписаном тексту, из пера Ђорђа Сп. Радојичића, објављеном као одговор на питање „Кад је Доситеј имао прилике да се упозна с

26 Очекивало би се да је Остојић о своме открићу обавестио Стојана Новаковића, обраћајући му се писмима поводом својих истраживања у хоповској библиотеци и писања студије о Доситеју. У писму писаном 28. априла/8. маја 1906., недељу дана пошто је „поднео Матици повећи рад којему је натпис “Доситеј Обрадовић у Хопову”, Остојић се распитује о манастирским уставима којима су регулисани организација и литургијски живот фрушкогорских манастира пре доношења Монащких ирравила митрополита Вићентија Јовановића 1733 (Државни архив Србије, СН 1909; Новаковићев одговор, 3. маја 1906: Р. Димитријевић, „Писма Стојана Новаковића Тихомиру Остојићу”, Прилози за кюижевност̄, језик, исйорију и фолклор (ПКЈИФ), 41, св. 3-4 (1975) 240-241 бр. 9). Писмо писано 22. августа/4. септембра 1906. још је занимљивије јер њиме, поред осталог, Остојић обавештава Новаковића о неким својим открићима у хоповској библиотеци - рукописним песмарицама, Доситејевој Буквици и Траеgокомеgији Мануила Козачинског. За ово последње вели: „Нашао сам рукопис оригиналнога текста, само је рђав и искварен”. О Сйирияонову зборнику, у којем су преписани и изводи из Козачинскове драме, нема ни речи, а камоли о препису Душанова законодавства (Државни архив Србије, СН 1910; Новаковићев одговор, 28. августа 1906: Р. Димитријевић, н. д., 242 бр. 12). Чудно је ово Остојићево ћутање, тим пре што је 1897, у време када је Новаковић увелико припремао критичко издање Душанова законика, овоме понудио рукописе Борђошких и Ковиљски и потом му послао њихове описе (Ст. Новаковић, Законик, LXXXVLXXXVI № 19, 20). Можда није сматрао важним да 1906. године (осам година после објављивања критичког издања Законика) обавештава Новаковића о открићу још једног у низу представника млађе редакције Душанова законодавства, јер му је било познато да овај није превише марио за рукописе XVIII века. Штавише, Новаковић је, у одговору на својевремену Остојићеву понуду два непозната рукописа, навео да би послате описе рукописа̂ ,уврстио на своје место, а од текста ми не треба ништа" (Рукописно одељење Матице српске, бр. 2446, Београд, 24. септембар 1897).

27 T. Ostojić, „,Dositheus Obradovićs Klosterjahre”, Archiv für Slavische Philologie, 30 (1909) 384-389. У српском преводу Страхиње Костића дело је објављено 1965: Т. Остојић,

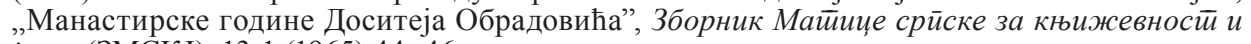
језик (ЗМСКЈ), 13-1 (1965) 44-46.

28 Зацело је остала непримећена јер је објављена у рубрици „Да ли знате?”, која је у то време штампана у Политикином Доgайку и то тако што су у једном броју постављана питања, а у наредном давани одговори на њих. У Политици од среде, 10. фебруара 1954 (бр. 14737) као прво питање наведено је: „Кад је Доситеј имао прилике да се упозна с Душановим закоником?", на страни 131 Политикиног Доgай ка, а у наредном броју (Политика, четвртак, 11. фебруар 1954, бр. 14738), на страни 135 Доgайка, налази се одговор. 
Душановим закоником?", налази се и сумарни опис садржине Сӣupиgонова зборника, према подацима што их доноси Остојић, и упозорење да је на његовом крају преписан Душанов законик. ${ }^{29}$ И наредних година податак о Душанову законику помиње се узгред, обично у радовима који су се бавили Спиридоном Јовановићем и његовим зборником или Доситејем Обрадовићем. Нема потребе све их наводити нити библиографски подаци које сам успео прикупити претендују на целокупност. Боривоје Маринковић у биографији Спиридона Јовановића, написаној за Лексикон писаца Југославије, на крају описа садржаја Сӣирияонова зборника наводи да се ту налазе и „два правна средњовековна споменика Јустиниијанов Кояекс и Дущанов законик." Веровао је да Сйирияонов зборник „данас није приступачан и познат”. ${ }^{30} \mathrm{y}$ Истиорији срискке књижевностии класищизма и ирреgроманйизма, објављеној исте године, Милорад Павић помиње да је Доситеј у Хопову читао зборник у коме се поред других дела налазио и Душанов законик. ${ }^{31}$ Лазар Чурчић у студији о Василију Крижановском (2002), чији је Катихизис преписан у Cūuрияонову зборнику, даје сумаран опис његове садржине, поменувши и Душанов законик. ${ }^{32}$ Боривоје Маринковић (2006), на истом месту на ком је решио загонтеку Вуловићева (Карловачког) рукописа, доноси, према Остојићу и Радојичићу, основне податке о Спиридонову препису Душанова законика, уз уверење да рукопис „данас није никоме [...] приступачан”. 33 Жарко Војновић (2018) у расправи о преписивачкој делатности у манастирима Карловачке митрополије у XVIII веку представљање Сӥирияонова зборника, према подацима које је био саопштио Остојић, завршава запажањем: „Зборник се окончава Јустинијановим и Душановим законицима". 34

„По некој чудној случајности Спиридонов препис, који је прелиставао и читао млади Доситеј, не помиње се у науци кад се набрајају рукописи Дущановог законика", ${ }^{35}$ исправно примећује Ђорђе Радојичић. Или, да се послужим речима Боривоја Маринковића, „Александар В. Соловјев није, зачудо, уочио један позни препис Дущщановоі законика из средине XVIII столећа, који је, такође, промакао истраживачима старог српског права!"36 Занимљи-

29 О Радојичићевом ауторству вид. Б. Маринковић, Б. Гаврилов, „Додатак 'Библиогра-

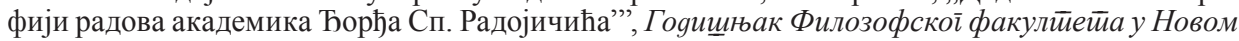
Cagy (Годишњак ФФНС), 14/2 (1971) 765, бр. 33. Текст је прештампан у књизи: Ђ. Сп. Радојичић, Кулимурно блаі̄o. Да ли знайе?, прир. С. Томин, Нови Сад 2006, 113.

30 B. Marinković, „Jovanović Spiridon”, Leksikon pisaca Jugoslavije, II, Novi Sad 1979, 623b. И у биографском огледу о Дионисију Новаковићу тврдио је да се рукопис налазио „својевремено у манастиру Хопову” (Б. Маринковић, „Скица за три портрета”, Гоgищъак ФФНC, 11/1 (1968), 227, 228).

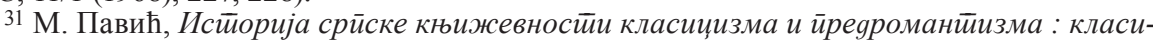
uизам, Београд 1979, 505. И у каснијим издањима: Рађање нове срйске књижевносиии : истиорија срйске књижевностии барока, класииизма и иреяроманйизма, Београд 1983; Преgроманйизам, Историја српске књижевности 4, Београд 1991, 167.

32 Л. Чурчић, „Трагови мало познатог професора новосадске Словенско-латинске школе Василија Крижановског”, Свеске Майице срйске, Серија књижевности и језика, 38 (10) (2002), 27-28 (= Исхоgи и сйазе срйских књиїа 18. века, прир. Д. Грбић, Нови Сад 2006, 31-32).

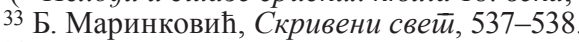

34 Ж. Војновић, „Преписивачка делатност у манастирима Карловачке митрополије у 18. веку”, Чийалищйе, 33 (2018) 59.

${ }^{35}$ Вид. нап. 28 и 29.

36 Б. Маринковић, Скривени свет̄, 537. 
во је да је чак и Никола Радојчић имао рукопис у рукама, али очигледно није тражио даље од извода из Хроника Ђорђа Бранковића, чији је предговор објавио управо према Спиридоновом препису. ${ }^{37}$ Како то да је дуже од једног столећа овај препис измицао пажњи проучавалаца Душанова законодавства?

Један од разлога за такав превид може делом почивати на чињеници да се подаци о Спиридонову рукопису налазе поглавито у делима која се не баве историјом права, било да помињу Душанов законик или не, као у следећим примерима. Рецимо, у студијама Властимира Ерчића о Мануилу Козачинском, чији се фрагменти дела̂ налазе у препису у Cüupugонову зборнику, ${ }^{38}$ или Владимира Вукашиновића о делима Дионисија Новаковића и Василија Крижановског. ${ }^{39}$ Други разлог би се могао наћи у (погрешном) уверењу да је рукопис у време Другог светског рата уништен или бар да се није могло утврдити каква је била његова судбина. Међутим, још 1961. Александар Младеновић је, бавећи се графијом раних Доситејевих записа, идентификовао рукопис и саопштио податке о месту његова чувања и сигнатуру, ${ }^{40}$ али и тај податак је већини истраживача који су се освртали на Сйирияонов зборник промакао, тим извесније што су се, по правилу, ослањали на Остојићеву студију. ${ }^{41}$

За разлику од преписа Душанова законодавства у Сйupиgонову зборнику, о чему се ретко писало, о преписивачу Спиридону Јовановићу постоји сразмерно обиље изворних вести, а већину их је први саопштио управо Тихомир Остојић. Заправо, од свих познатих преписивача Душанова законика, поглавито оних из XVIII века, о Спиридону се највише зна. Рођен је у Београду 1719,42 а школу је изучавао код познатог београдског учитеља даскала Стефана, што се, још од Остојићеве студије, погрешно идентификује са Стефаном Стојковићем, архиепископским егзархом, од којег су остала два преписа Душанова законодавства - Ковиљски и Софијски. ${ }^{43}$ Хоповски искушеник

37 Н. Радојчић, „О Хроникама грофа Ђорђа Бранковића”, ПКЈИФ, 6 (1926) 13-15.

38 В. Ерчић, Мануил (Михаил) Козачинскиј и њеі̄ова Траеgокомеgија, Нови Сад - Београд 1980, 399 нап. 17, 414 нап 233, 430-432; М. Радоњић, „Козачински Мануил/Емануил”, Енциклойеguja СНП, https://www.snp.org.rs/enciklopedija/?p=6395 (приступљено 14. септембра 2021).

39 Вукашиновић редовно наводи где се чува Сйирияонов зборник и његову сигнатуру: В. Вукашиновић, „Новосадски богословски рукописи: Василије Крижановски и Дионисије

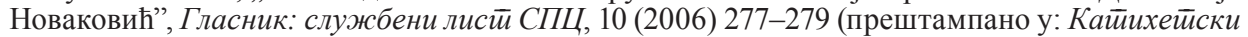
йриручници, прир. Д. Грбић, Р. Станковић, Ћирилске рукописне књиге Библиотеке Матице српске, Књ. XVI, Нови Сад 2014, 146 нап. 14). Ту се, због штампарске грешке, даје погрешна сигнатура - 27 уместо 127. Тачни подаци у монографији Срйска барокна йеолоїија : библијско и светиойајинско бойословље у Карловачкој митиройолији XVIII века, Београд - Краљево - Нови Сад 2008, 150 нап. 213; и у издањима из 2010. и 2017.

40 А. Младеновић, „Анализа графије првих рукописа (записа) Доситеја Обрадовића из манастира Хопова, Крке и Драговића", Гоgищщъак ФФНС, 6 (1961) 243, 246; исти, Извещйај о научноисйраживачком раgу, на истом месту, 409.

41 Осим радова наведених у нап. 30-34, вид. М. Тишма, „Јовановић Спиридон”, Срйски биоірафски речник (СБР), 4, Нови Сад 2009, 632-633; Ж. Војновић, Срсйке манасииирске библиотиеке gо краја XVIII века, Панчево 2019, 2020², 124 нап. 297.

42 Приликом визитације фрушкогорских манастира 1753. забележено је да Спиридон има 34 године (Д. Руварац, Ойис срӣских фрущикойорских манасйира 1753. і̄og., Сремски Карловци 1903, 226), а приликом визитације 1771. 52 године. Исти, „Опис фрушкогорских манастира од 1771. године", Архив за исӣорију Срйске йравославне Мийройолије карловачке, год. III, св. 2 (1913), 104.

43 Идентификација није могућа из више разлога: 1) Стефан Стојковић био је монах и имао чин синђела, а даскал Стефан био је световно лице; 2) у време када је Стефан учитељ 
постао је 1735, постригао се на Божић 1738, а наредне године рукоположен је за јеромонаха. ${ }^{4}$ Због блиских веза с епископом пакрачким Софронијем Јовановићем, такође хоповским пострижником, једно време током пете деценије XVIII века био је учитељ у Пакрацу и Осеку. 45 У време визитације фрушкогорских манастира јула 1753. поново је био у Хопову, добио је карактеристику, ретку за тадашње необразовано монаштво: „В писанији искусан, читати, појати и писати изрјадно знајет”. Због тога је постављен за типикара и магистра манастирског, с обавезом да води манастирске протоколе, да подучава братију и прњаворску децу читати и писати као и да подучава децу и слуге манастирске вери недељом, празницима, пре литургије и пре вечерње..$^{46}$ Будући да су наредне године Хоповци предњачили у отпору фрушкогорских манастира настојањима митрополита Павла Ненадовића да искорени „осопштину”, Спиридон је у тим збивањима одиграо запажену улогу. ${ }^{47}$ Нема података о томе да је трпео последице након што је митрополит скршио отпор непослушних игумана, али рекло би се да није случајност што га у новембру налазимо у Пакрацу, на двору свога заштитника епископа Софронија Јовановића, са звањем „епископски служитељни ефимериј протонотаријус". ${ }^{48}$ Тада је добио од епископа руски штампани требник. ${ }^{49}$ Изгледа да се вратио у Хопово тек после смрти епископа Софронија (25. децембра 1757), који је тестаментом наменио 100 форинти „Спиридону ефимерију", 50 а не помиње се у записнику с манастирског сабора, одржаног 22. јула 1757. у присуству митрополита, на којем је за протоколисту манастирског именован јеромонах Василије Недељковић. ${ }^{51}$

Премда учен, радознао, високо писмен, добар познавалац теологије и тадашње науке и образованости, брижљив преписивач, Спиридон је био несталне, луталачке и неукротиве природе - „несташни Београђанин”, како

(мештер, даскал) у Београду, Стефан Стојковић је прво егзарх ваљевског владике, а потом и архиепископско-митрополитски егзарх; 3) крајем августа 1733. бележи се да је даскал Стефан имао осам ученика, а Стефан Стојковић тада се налазио у Карловцима итд. О даскалу Стефану вид. Ист̄орија Беоїраgа, књ. I, Београд 1974, 552-553, а о Стефану Стојковићу вид. Ђ. Бубало, „Историја и историографија рукописа”, Законик иара Сйефана Дущана, Књ. IV, T. I, 31-33.

44 Д. Руварац, Ойис 1753, 226; исти, Ойис 1771, 104; Т. Остојић, Досийеј у Хойову, 265.

45 Д. Руварац, Ойис 1753, 232; Т. Остојић, нав. месиио. Упор. А. Кучековић, „Епископ Софроније Јовановић (1743-1757) и барокни културни модел у Пакрачко-славонској епархији”, Три века Карловачке митиройолије, 1713-2013, Нови Сад 2014, 604.

46 Д. Руварац, Ойис 1753, 55, 238.

47 Т. Остојић, Досийеј у Хойову, 48-51, 54, 59.

48 Ефимерије је био високорангирани дворски службеник на патријарашком и владичанским дворовима; био је лични капелан и саветник архијереја и старао се о дворском протоколу. Уз то, обављао је и дужност протонотара. Према томе, Спиридон је морао бити особа од нарочитог владичиног поверења. О дужности ефимерија вид. Д. Руварац, „Дужности и права дворјана и дворских служитеља за време митрополисања Мојсеја Петровића", Срйски Сион, год. XVII, бр. 27 (1907) 418, 420-421; исти, „Дужности и права дворјана и дворских служитеља за време патријарховања Арсенија Јовановића Шакабенте", Срйски Сион, год. XVII, бр. 33 (1907) 504; М. Тимотијевић, „Богородица Бездинска и верско-политички програм патријарха Арсенија IV Јовановића", Balcanica, 32-33 (2003) 327-333.

49 Љ. Стојановић, Зайиси и наӣӣuси, II, бр. 3067. В. Marinković, Jovanović Spiridon, $623 \mathrm{~b}$, погрешно убраја ову штампану књигу међу Спиридонова преписивачка дела.

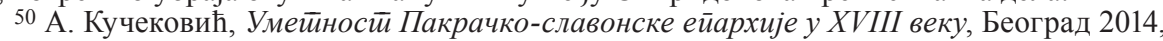
$51,92$.

51 Т. Остојић, Досийеј у Хойову, 204-205. 
га духовито назива Властимир Ерчић. 52 Често је бежао из манастира, а након покајничких повратака сваки пут је потписивао реверсе којима се неискрено обавезивао да за живота више неће напуштати постриг. ${ }^{53}$ И поред повремених испада, његова знања и вештине били су потребни манастиру па је у лето 1759. поново постављен за протоколисту и магистера, а почетком 1760. добио је овлашћење да учи појању млађе јеромонахе и ђаконе. 54 У јуну 1760. побегао је седми пут и скитао се по Турској до повратка у априлу наредне године. Тада се за њега код митрополита заузео, као и 1759. приликом једне од бежанија, потпуковник Александар Рашковић из Петроварадинског пука, ${ }^{55}$ па је успео да се провуче без озбиљније епитимије уз обећање да му је то последњи пут. За казну је годину дана морао да помаже у кухињи, да доноси воду и дрва, није смео да учествује у раду братског сабора ни у богослужењу, да напушта манастир нити да коме пише. Ако би поновио грех трајно му се забрањивао повратак у манастир. ${ }^{56}$ Штавише, 18. јуна 1762 . по казни је премештен у манастир Фенек. 57 До 1766. вратио се у матични манастир, а 8. септембра 1770, митрополит Јован Георгијевић именовао га је за игумана Врдника. 58 У том манастиру подигнута је чесма 1772 . при игуману кир Спиридону. 59 У Хопово се вратио 1773, јер је 24. октобра те године за новог врдничког игумана изабран јеромонах Василије. ${ }^{60}$ Умро је 22 . априла 1782, пошто је претходно дуго побољевао. ${ }^{61}$

Осим обимног рукописа с преписом Душанова законодавства, Спиридон је оставио иза себе бројне белешке и преписе аката у протоколима манастира Хопово, поглавито из шесте деценије XVIII века. Њима се служио Остојић пишући студију о Доситеју Обрадовићу, али су страдали с манастирском архивом у Другом светском рату. Осим тога, по одликама графије и запису о преписивању, са сигурношћу му се приписује рукопис Српског летописа, који се данас чува у Шафариковој збирци у Народном музеју у Прагу (сигн. IX H 4 [క̌ 27]). ${ }^{62}$ Према запису, грешни и злополучни Спиридон Хоповац преписао је рукопис за игумана Велике Ремете Атанасија Исаијевића, 2. јула 1762. у манастиру Фенеку. ${ }^{63}$

52 В. Ерчић, н. д., 430.

53 Т. Остојић, Досийеј у Хойову, 264.

54 Исто, 277, 294, 295.

55 О њему вид. П. Штрасер, Кїийори и ирриложници манасӣира Бещенова у XVIII веку, Сремски Карловци 1996, 16, 24. Рашковић је морао имати неки разлог да код митрополита оправдава непослушног хоповског монаха. Спиридон је, како стоји у извештају о визитацији 1753. год., имао сестру у Новом Саду. Можда је управо то Ана, супруга Александра Рашковића. Уколико јесте, онда је Спиридон морао потицати из добростојеће породице.

56 Т. Остојић, Досийеј у Хойову, 306.

57 Исто, 265, нап. 12.

58 С. Попић, Ойис Манастиира Вряника-Раванице у Срему, Сремски Карловци 1898, 47; Д. Руварац, Ойис 1771, 104, 106. бр. 1687.

59 П. Момировић, Се̄иари срйски зайиси и найӣиси из Војвоgине, књ. 1, Нови Сад 1993,

${ }^{60}$ С. Попић, нав. мест̄о

${ }^{61}$ Т. Остојић, Досийеј у Хойову, 266.

62 И. Шпадијер, В. Тријић, З. Ракић, З. Ранковић, Срйске рукойисне књиіе у Чещккој, Београд 2015, 78-79, бр. 21 и снимак на стр. 222.

63 Љ. Стојановић, Зайиси и нат̄ӣuси, II, бр. 3196; J. Vašica, J. Vajs, Soupis staroslovanských rukopisu Národního musea v Praze, Praha 1957, 294. 
Иринеј Радић, игуман хоповски, у својој историји манастира Хопова објављеној 1847, помиње „рукописну повест, минејску весма опширну” о св. Теодору Тирону, коју је написао 1780. Спиридон Јовановић. ${ }^{64}$ На основу овога податка усталило се уверење да је реч о још једном рукопису писаном Спиридоновом руком. 65 Тек 1997, у постхумно штампаној збирци записа и натписа Владимира Ћоровића, објављен је и запис са овога рукописа из којег се види да је „старац Спиридон” заиста написао Повест о св. Теодору Тирону, будући „привољен бист” од архимандрита Јована Јовановића и игумана Василија Недељковића, али да је у том рукопису препис јерођакона хоповског Порфирија из 1780.66 Рукопис се данас чува у Библиотеци Српске патријаршије (бр. 285). Добротом њеног управника др Зорана Недељковића имао сам прилику да прегледам ту књижицу и уверим се да није писана руком Спиридоновом и да је Ћоровић без грешке прочитао запис. Пошто је заједничко старешинство архимандрита Јована и игумана Василија у Хопову почело $1776,{ }^{67}$ Спиридоново дело настало је у раздобљу $1776-1780$, али аутограф до данас није пронађен. 68

Његов највећи подухват ипак је рукописна књига Грујићеве збирке, бр. 127, обима 562 листа, несвакидашња по разноврсности садржине, по ретким или јединственим преписима и изводима и, наравно, по целовитом препису Душанова законодавства млађе редакције. У њој нема Спиридонова записа о томе када је и где окончао преписивање свога обимног зборника, али се одговори на та питања, према неким Спиридоновим интервенцијама у тексту и датацији водених знакова, могу добити. На листовима 49б-50б Спиридон је преписао пролог и три позоришне песме из прве српске позоришне представе - Tpaegoкомеguje Мануила Козачинског (први пут изведене 1736). ${ }^{69}$ Једну од њих - Преславна Сербије - преименовао је у Преславна Славоније (с наднасловом Канй

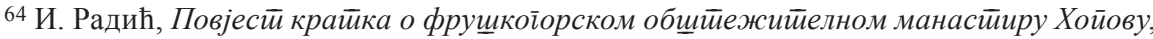
Будим $1847,29$.

65 Вид. нпр. Д. Руварац, „Житије Св. Теодора Тирона”, Срйски Сион, год. XIV, св. 20 (1904) 605; B. Marinković, Jovanović Spiridon, 623b; B. Gugolj, „,The St. Theodore Tyron cult in

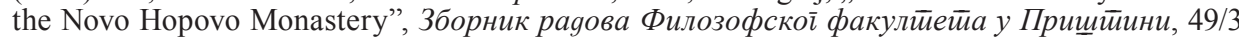
(2019) 172. бр. 131.

${ }^{66}$ В. Ћоровић, Сйари срӣски зайиси и найӣиси, прир. Р. Михаљчић, Београд 1997, 67

67 Д. Ковачевић, И. Јокић, Н. Ковачевић, „Настојатељи манастира Хопова у XVIII веку”, Сйоменииа Исӣоријской архива „Срем”, 2 (2003), 42-43.

68 Сачуван је још један рукопис са текстом Повести о св. Теодору Тирону, писан у последњој четврти XVIII века, нема записа, а према одликама графије јасно је да то није Спиридонова рука. Рукопис се чува у Библиотеци Матице српске. Инв. бр. 113456; стара сигнатура РР 190; И. Веселинов, „Повест о Теодору Тирону”, ЗМСКJ, 16/2 (1968), 216-231; прештампано у: Трайом срйске йрощлосӣu, Нови Сад 1991, 79-97; Иста, „Српске ћирилске рукописне књиге XVIII века у Библиотеци Матице српске (3). II Недатиране”, Гоgищъак Библиойеке Майиие срйске, 6 (1981), 120-121, бр. 46.

69 М. Радоњић, „Козачински Мануил/Емануил”, Енциклойеguja СНП, https://www.snp. org.rs/enciklopedija/?p=6395 (приступљено 14. септембра 2021); Ђ. Перић, „Прва позоришна песма - Плач мајке цара Уроша", Енциклойеguja СНП, https:/www.snp.org.rs/enciklopedija/?p=14753

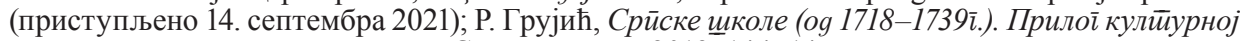
исйорији срйской анароgа, Нови Сад - Београд 2013, 144-147. У критичком издању Tраеgокомеguје Козачинског дата су и разночтенија из Спиридонова преписа та четири фрагмента (В. Ерчић, н. д., 430, 440-441, 496-499, 548-551, 558-563). 
Славонији), а уместо имена карловачког митрополита Вићентија Јовановића унео је име свога заштитника, епископа пакрачког Софронија Јовановића. ${ }^{70} \mathrm{y}$ наставку, на листовима 50б-56б преписана су два Приветисиивија Козачинског (оде у тринаестерцу, похвалне песме, ентрате) - прво митрополиту Вићентију Јовановићу ${ }^{71}$ поводом његова повратка из Беча у јесен 1735 , и друго епископу костајничком Стефану Љубибратићу. Иако су писане у акростиху тако да почетна слова свакога другога стиха откривају идентитет слављеника - Внкєнтїй

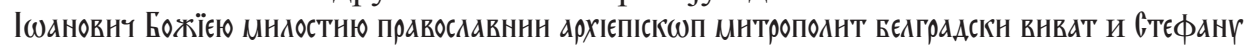

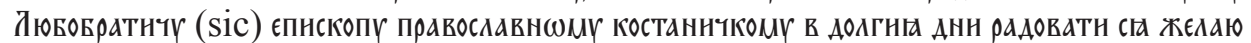

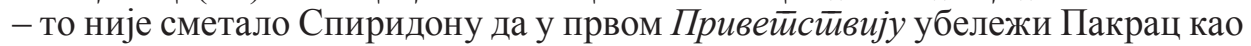
архијерејско седиште, у стиховима: Пьто сє єсть шєсто како ты радншн // На прєстолЂ пакрачком[ь], правндно сҚАншн, ${ }^{72}$ и да изостави име Мануила Козачинског као аутора, а у другом да унесе име Софроније уместо Стефан и Пакрац уместо Коста(j)ница. ${ }^{73}$ Будући да је у тренутку писања Привестистивија била шеста година Софронијева намесништва у Пакрацу,${ }^{74}$ како стоји у горе наведеним стиховима, то значи да је Спиридон прерађивао и преписивао ове похвалне песме 1749 , управо у време када је учитељевао у Пакрацу.

Исте године преписао је и Ейийом Дионисија Новаковића, на лл. 197а$218 \mathrm{a}$, ставивши и ово дело под благослов епископа „пакрачко-славонског и осечкопољског" Софронија Јовановића уместо оригиналног покровитеља, епископа бачког, сегединског и јегарског Висариона Павловића, а годину настанка дела - 1741 - заменивши годином преписивања. На лл. 340а-363б Спиридон је преписао извод из Хроника грофа Ђорђа Бранковића, а одмах након предговора унео запис о преписивању (л. 341a). У њему читамо да је Хронику Славеносрбску преписао Спиридон Хоповски у време када је био учитељ у осечкој школи, при епископу пакрачком Софронију и архиеписко-

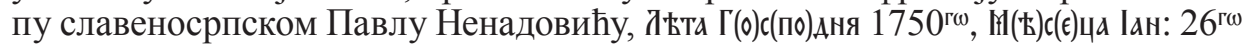
B’ Аолней осєчкон варошн..75 Дакле, састављајући овај зборник Спиридон је већ загазио у 1750. годину и, ако није правио веће застоје, сва је прилика да је те године преписивање и окончао. Т. Остојић се чак носио мишљу „да су поједини чланци прво писани на засебним свесцима који су после укоричени уједно и скупа пагинирани". 76 Међутим, не можемо знати да ли је рукопис био довршен у Осеку или Пакрацу или пак када се Спиридон вратио у Хопово, где га срећемо најкасније почетком јула 1753, у време визитације

70 Упор. В. Ерчић, н. д., 560-563, 668-669.

${ }^{71}$ О тој песми упор. Р. Грујић, Срйске щиколе, 142-144; В. Ерчић, н. Д., 202-210; издање оригиналнога текста: Р. Грујић, „Прилози за историју српских школа у првој половини XVIII века", Сйоменик CKA, 49 (1910), 132-134.

72 У оригиналу пише, према издању Р. Грујића, исто, 134: „Льто се єсть пятое, какш ты радиши // На престоль бълград“скомъ правилно сьдиши”.

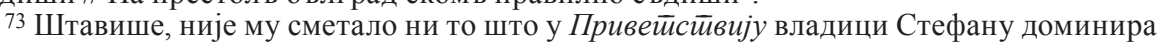
мотив прогона, тамновања и блиске смрти, свакако као алузија на његово протеривање с територије Млетачке републике 1722.

74 Постављен је за пакрачког епископа у марту 1743. О њему вид. Б. Цинцар-Костић, „Јовановић, Софроније”, СБР, 4, Нови Сад 2009, 631-632.

75 Издање записа: Збирка Раgослава М. Грујића, I-1, 195. У осечкој Доњој вароши епископ Софроније имао је резиденцијалну кућу (А. Кучековић, Умейносй Пакрачко-славонске eйapxuje, 50).

76 Т. Остојић, Досийеј у Хойову, 377. 
манастира. ${ }^{77}$ Рекло би се да је већ током друге половине те године послужио као предложак за преписе појединих дела из његова састава. Наиме, у јануapy 1754. г. довршено је преписивање зборника (МСПЦ 13) у који су преписани неки састави из Спиридонова рукописа, поред других - Сӣойлав па-

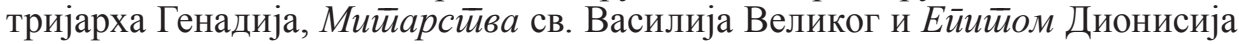
Новаковића, са истоветним насловом у којем се наводи покровитељство епископа Софронија и година 1749. Име преписивача није уписано, али је доцније књига припадала јеромонаху Ћирилу, хоповском пострижнику. ${ }^{78}$

Сйирияонов зборник радо се читао међу хоповском братијом. Крајем априла 1759. хоповски јеромонах Стефан оставио је запис на 196. листу - до

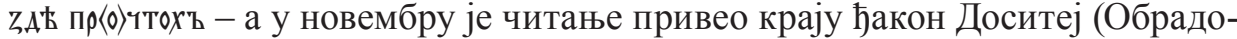
вић). Грешни јерођакон Атанасије забележио је 1777. да читајући књигу много ва ней полzовахся. Рукописна књига није била уврштена у манастирску библиотеку већ је, по свој прилици, за Спиридонова живота остала у његову поседу. На полеђини 1. листа неко је 1. децембра 1766. забележио: Сїа кннга Спнрндона Їєромонах[а] н пострнжннка хоповскагш, вероватно у време док је био по казни у Фенеку. Спиридон ју је позајмљивао и световњацима - новосадски трговац Лазар Исакович завршио је читање 12. фебруара 1782, два месеца пре Спиридонове смрти, захвално ускликнувши: о[ть]ць Спйрїдонє, вєчна тї радос〈ть〉. Последњи податак о изношењу књиге из манастира настао је 10. априла 1795 , када је извесни Јо[ван] вратио књигу Стефану Коларевичу. ${ }^{79}$

Спиридонов зборник налазио се до почетка Другог светског рата у фонду манастирске библиотеке, под бројем 125. Тамо га је нашао Тихомир Остојић 1906, потом Никола Радојчић две деценије доцније. Манастир Хопово, са својом богатом ризницом, архивом, библиотеком и збирком рукописа, био је препуштен систематском уништавању након хрватске окупације Срема 1941. Комисија с Владимиром Ткалчићем на челу, која је боравила у манастиру септембра 1941, преузела је и пренела у Музеј за умјетност и обрт у Загребу само богослужбене и уметничке предмете. У записницима о преузимању манастирских драгоцености и оним о њиховом повраћају 1946. не помињу се хоповски рукописи, већ само појединачна документа и књиге. 80 Учесници и сведоци отимања и враћања културног блага фрушкогорских манастира сложно истичу да није било организованог преноса манастирске архиве и библиотеке, те да није позната судбина рукописне збирке манастира Хопово. ${ }^{81}$ Милан Костић, председник Покрајинске комисије за утврђивање злочина окупатора у Војводини, у елаборату „Злочини на културноисторијским споменицима и предметима у Срему”, састављеном 1946. године, тврди да је из

77 Рукопис, међутим, није евидентиран ни међу Спиридоновим књигама ни у фонду манастирске књижнице (Д. Руварац, Ойис 1753, 226, 249-250). бр. 74 .

78 С. Петковић, Ойис рукойиса манастиира Крущееgола, Сремски Карловци 1914, 194-197

79 Т. Остојић, Досиӣеј у Хойову, 377; Збирка Раяослава М. Грујића, I-1, 194, 196-197.

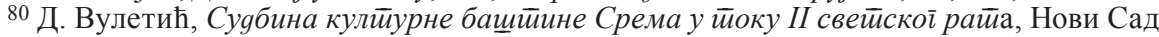
1992, 46-48, 206, 214, 257-258, 260-261.

81 J. Попов, „Библиотеке и књижнице у Војводини за време Другог светског рата”, Збор-

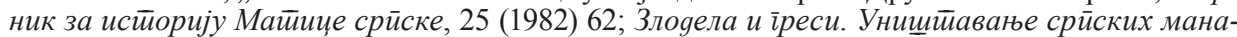
стиира и иркава. Сремска ейархија 1941-1945-1950, предисловије Д. Давидов, Београд 1990, 31, 132, 214; Д. Вулетић, н. Д., 270, 281. 
Хопова сачувано „само 15 комада старих рукописних књига, што су непосредно пред рат ове књиге пренете у патријаршијску библиотеку".82 То би могао бити један од начина којим је рукопис евентуално доспео у Грујићеве руке и у његову се поседу задесио у тренутку смрти 1955. Није ипак искључена могућност да се Сйирияонов зборник обрео у Загребу током рата и да је с другим драгоценостима враћен Српској патријаршији 1946. У Комисији која је организовала и надгледала повраћај српских црквених драгоцености из Загреба представник Светог архијерејског синода био је управо Грујић, ${ }^{83}$ па се и тим путем, уколико га је узео ради проучавања, рукопис из некадашње хоповске библиотеке могао обрести у његовој Оставини у Музеју СПЦ.

По садржини, Хоповски препис не доноси ништа ново. То је типичан представник карловачке гране млађе редакције Душанова законодавства, који иде у исту скупину с Патријаршијским, Борђошких, Текелијиним, Сандићевим, Ковиљским, Софијским, Београдским, Карловачким и Вршачким рукописом. Као и наведени рукописи, садржи текстове Закона Константина Јустинијана и Душанова законика у уобичајеном обиму и распореду грађе, укључујући и особени редослед чланова Душанова законика потекао од изгубљеног протографа карловачке верзије поремећеног редоследа листова. Прелиминарно текстолошко поређење Хоповског преписа с другим преписима карловачке верзије показује да се његов непосредни (или посредни) предложак може идентификовати међу сачуваним преписима.

Према систематизацији и нумерацији садржинских целина Душанова законика - којих има 97 - Хоповски иде у исту групу с рукописима Борђошких, Сандићевим, Ковиљским и Софијским. ${ }^{84}$ Закон Константина Јустинијана, премда је истог обима и састава као и у поменута четири рукописа, има 91 члан напрама 87, и то као резултат другачијег нумерисања целина (груписање два члана под једним бројем или подела једног члана на два нумерисана). ${ }^{85}$

Према осталим текстолошким одликама, Хоповски показује највећу блискост са Сандићевим, Ковиљским и Софијским рукописом, а у оним варијантама, укључујући грешке и испуштања текста, у којима Сандићев одступа од Ковиљског и Софијског (који су, као што је наведено, дело истог писара) Хоповски прати Сандићев. ${ }^{86}$ Ради илустрације овде пружам само неколико примера, прво из ЗКЈ:87

82 Злояела и ірреси, 146.

83 Упор. Н. Идризовић, „Патријаршијска библиотека за време Другог светског рата и непосредно после њега", Гласник Нарояне библиойеке Србије, 18 (2016) 183-206. У записнику о преузимању црквених драгоцености, сачињеном 8. јуна 1946. у Загребу, наводи се и „Сандук с књигама манастира Хопово”, али да ли су у њему биле само штампане књиге или и рукописи не може се знати (Д. Вулетић, н. д., 247, бр. 292).

84 Законик изара Сйефана Дущиана, Књ. IV, T. I, 593-596.

85 Истини за вољу, и у Карловачком рукопису препис Закона Константина Јустинијана има 91 нумерисани члан, али је расподела, груписање и нумерација грађе другачије спроведена (Б. Марковић, Јусӣинијанов закон, 138-141, 247-276).

86 Та текстолошка подударања могу се лако пратити у тексту Закона Константина Јустинијана и без увида у рукопис, посредством његова издања у којем су међу разночтенијима наведена и она из Сандићевог (тамо именованог Стратимировићев), Ковиљског и Софијског рукописа.

87 У навођењу текстолошких разлика користиће се следеће скраћенице: Хоп - Хоповски рукопис; Сан - Сандићев рукопис; ДЗ - Душанов законик; ЗКЈ - Закон Константина Јустинијана; МСПЦ - Музеј Српске православне цркве; БМС - Библиотека Матице српске. 
чл. $9^{88}$ - Хоп и Сан изостављају други део прописа од речи: Ащє 九н оү нощн Бєреть...;

чл. 13 - Хоп и Сан грешком првратнть уместо повратыть;

чл. 31 - Сан грешком црьковскомв, по њему Хоп црыковномв уместо царьскомв;

чл. 39 - Хоп и Сан

чл. 50 (52 Хоп) - први одељак истоветно формулисан у Хоп и Сан;

чл. 66 (69 Хоп) - Хоп и Сан изостављају претпоследњу реченицу: Ащє

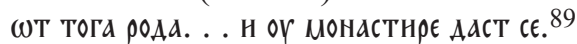

Слична поклапања могу се идентификовати и у тексту ДЗ:

чл. $52^{90}$ - предлошко-падежну конструкцију за неверв Сан преиначава у везник и именицу занє вєр8, а по њему и Хоп: занє вЊр8;

чл. 107 - Хоп и Сан грешком срамоволань уместо самоволань;

чл. 118 - Хоп и Сан грешком нн по-сндннце заграднтн уместо нн по-снднце загравнтн;

чл. 151 - Хоп и Сан грешком zа помннаніє уместо zа поманє. ${ }^{91}$

Предложак Хоп још се убедљивије показује поремећајем у редоследу чланова ЗКЈ који је последица погрешног слагања неколико листова приликом повезивања или преповезивања Сан. Наиме, листови 19 и 20 увезани су пре листова 17 и 18, тако да се листови нижу овим редоследом: 16, 19, 20, 17, 18, 21, 22 итд.92 Другим речима, заменили су места 6. и 7. лист и 4. и 5. лист треће свешчице, вероватно и зато што су у тренутку повезивања били волантни. Уз то, повезивање је учињено након што су листови и прописи били нумерисани. Нови редослед листова Сан озакоњен је новом фолијацијом, графитном оловком индоарапским цифрама на горњој маргини, те је л. 19 добио број 17, 20 $\rightarrow 18,17 \rightarrow 19$ и $18 \rightarrow 20$. Управо на месту где почиње текст на погрешно увезаном листу 19 (сада 17) Сан, долази и до прекида текста у Хоп. На пола члана 52 (према нумерацији у издању; у Хоп је то чл. 54), текст се наставља другим делом члана 57,93 а следе му чланови 58, 59, 60, 61 и први део чл. 62,94 баш као на листовима 19 и 20 Сан (тј. 17 и 18, према новој фолијацији). Затим у Хоп следи текст који се налази на листовима 17 и 18 Сан (тј. 19 и 20, према новој фолијацији) и то, други део прекинутог члана 52 , потом чланови $53,54,55,56$ и први део чл. 57. На листу 21 Сан наставља ce 62. члан, баш као и у Хоп, где првом делу чл. 57 следи други део чл. 62,95 с тим што је у Хоп изостављен текст који је исписан у првом реду л. 21 Сан:

${ }^{88}$ Нумерација чланова у издању.

89 МСПЦ, Грујић бр. 127, лл. 526б, 527а, 528б, 530а, 531б; Б. Марковић, Јусииинијанов закон, 76, 78, 85, 89, 96.

90 Према Новаковићевој нумерацији.

${ }^{11}$ МСПЦ, Грујић бр. 127, лл. 539б, 543а, 543б, 545б; Законик ияара Сиеефана Дущана, Књ. IV, T. I, 282, 290, 291, 294.

92 Д. Грбић, К. Шкорић, љ. Васиљев, Дущианов законик. Борђощкой, Николајевићев,

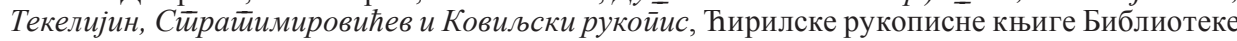
Матице српске, књ. ХІІІ, Нови Сад 2008, 63-64; Љ. Васиљев, „Опис Сандићевог рукописа”, Законик изара Сйефана Дущиана, Књ. IV, T. I, 301. Снимци Сан доступни су у Дигиталној колекцији Библиотеке Матице српске

93 Бројеви чланова ЗКЈ дати су према нумерацији у издању, осим на местима где је другачије упозорено.

94 МСПЦ, Грујић бр, 127, лл. 530а-530б.

95 МСПЦ, Грујић бр. 127, лл. 530б-531а. 
ндн нннцъ прнємнїкои' єго: . Нови редослед чланова потврђен је у Хоп континуираном нумерацијом, тако да чл. 54 Хоп садржи текст првог дела чл. 52 Сан и други део чл. 57. Однос нумерације у наставку је:

$$
\begin{aligned}
& 55 \text { (Хоп) : } 58 \text { (Сан) } \\
& 56: 59 \\
& 57: 60 \\
& 58: 61 / 62.1 / 52.2 \\
& 59: 53 \\
& 60: 54 \\
& 61: 55.1 \\
& 62: 55.2 \\
& 63: 56 \\
& 64: 57.1 / 62.2 \\
& 65: 63 \text { итд. }
\end{aligned}
$$

Нема никакве сумње да поремећај у редоследу прописа који одликује текст ЗКЈ у Хоп има своје исходиште у погрешно увезаним листовима Сан. Тај рукопис настао је око 1724, а у следећој четврти 18. столећа морао је бити преповезан или први пут повезан, тј. добити редослед листова какав се одсликава у редоследу чланова ЗКЈ у Хоп, преписаном око 1750. Уз горе наведена текстолошка подударања, то би требало да буду чврсти аргументи у прилог уверењу да је предложак Хоп био управо Сан.

Међутим, треба скренути пажњу и на разилажења између два рукописа, 96 а разлика у укупном броју чланова ЗКЈ, сходно систематизацији грађе, није једина између два текста. Честе су варијанте интегритета, поглавито испуштања текста:

- типски наслови или уводне формуле прописа у ЗКЈ, мада недоследно: речє Благочьстнвн царь и Zакон’ царьскн, док су у ДЗ потврђена само два случаја;

- цели чланови: само један случај у Д3; изостављен је чл. 18 (према нумерацији Бор, Сан, Ков и Соф; одговара чл. 49 Новаковићеве нумерације); 97

- делови реченица: осим наведеног примера с почетка л. 21 Сан, у чл. 14

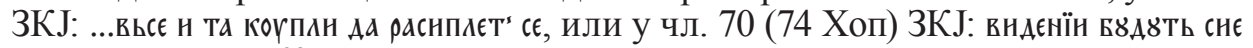
СМЕВ'ШєЕ СЪТТОрНТН; 98

- појединачне речи: на много места, углавном у ЗКЈ. ${ }^{99}$

Рекло би се да су изостављања речи или делова текста резултат редакторских захвата преписивача, јер су изостављене углавном сувишне речи, понављања, реторски украси. Ниједна од ових интервенција није променила или замаглила смисао прописа. У случају чл. 18 ДЗ, тај пропис је писарским погрешкама у Сан толико искварен да је постао тешко разумљив те га је можда зато Спиридон и прескочио.

Ређи су случајеви допуна текста, и то само у ДЗ:

96 У наставку су наведени само одабрани примери.

97 МСПЦ, Грујић бр. 127, л. 539б; Законик иара Сйефана Дущана, Књ. IV, T. I, 282.

98 БМС, РР І 34, лл. 4б, 28а; МСПЦ, Грујић бр. 127, лл. 527a, 533а. 73-109).

99 За илустрацију вид. разночтенија у издању ЗКЈ (Б. Марковић, Јусиичнијанов закон, 
чЛ. 150 - нг, огня горящєє голою р8кою уместо

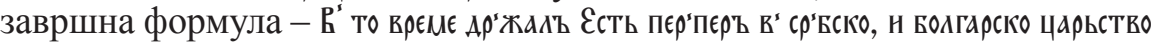

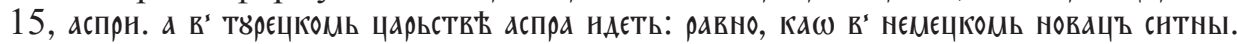

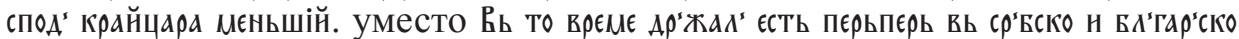
царьство єН аспрн. ${ }^{101}$

Чак и у писарским грешкама, којима се Хоп издваја од свих осталих рукописа, може се препознати утицај предлошка, у којем су речи биле нејасно написане:

чл. 6 ЗКЈ - одєла мвжєва уместо Фт дъла ивжєва (у Сан је једва видљива титла изнад $\omega$, које је написано спојено с именицом која му следи, тако да је Спиридон ту предлошко-падежну конструкцију прочитао као именицу);

чл. 7 ЗКЈ - Ако тко правд४ zавр'жєть уместо Аџє кто вражд४ zав'рьжєть (У Сан в изгледа као п, а ж би се услед нејасних обриса првог слова у речи могло учинити и прочитати и као в);

чл. 63 ЗКЈ (65 Хоп) - Ад онєн уместо даннєн (у Сан између а и н исписано још једно слово па замрљано; могло се прочитати и као $\omega)$;

чЛ. 45 ДЗ - нє поднгнє Уместо нє поАгонє (У Сан иза надметнутог А написано па пребрисано слово и изнад њега дописано г). ${ }^{102}$

Има случајева у којима се Хоп разилази од Сан (и других ркп.) као последица наума преписивача да учини јаснијим прописе или као израз његова тумачења прописа, као и у две, раније наведене допуне. Ево неких примера: наслов ЗКЈ - СІА КННГА ГЛАГОЛЕНЯЯ С४ДЕНСКАЯ уместо СЇА КННГА ГЛАГОЛЮНН с४дАЦь

чЛ. 16 ЗКЈ - под' старєшнномь Уместо под старєншїМь;

чЛ. 32 ДЗ - ПоА’АаннКє УМесто Посаднїкє;

чЛ. 132 ДЗ - да га окрнвєть Уместо Аа га шправєть, јер је Спиридон протумачио одредбу тако да онога који купује опљачкану ствар свакако треба окривити, а не оправдати пред поротом. ${ }^{103}$

У Сан, у наслову ЗКЈ, име цара Јустинијана погрешно је написано Иогстнана. ${ }^{104}$ Спиридон је исправио ту грешку - Івстннїана ${ }^{105}$ - свакако јер је по својој учености морао знати право име тог византијског цара. Осим тога, у рукопису га на другим местима неколико пута пише правилно - у изводима из Баронија и у опису Петог васељенског сабора. ${ }^{106}$

Најзанимљивији је ипак случај његова тумачења средњовековне именице сєБарь. Њено значење није му било познато па је настојао да је тумачи према контексту прописа. При првом сусрету мислио је да је посреди писарска грешка у предлошку и „себра” је преиначио у „серба/сербина” (Србина):

100 МСПЦ, Грујић бр. 127, л. 545б; Законик ичара Сйефана Дущиана, Књ. IV, Т. I, 294.

101 МСПЦ, Грујић бр. 127, л. 548а; Законик иара Сйефана Душиана, Књ. IV, Т. I, 299.

102 МСПЦ, Грујић бр. 127, лл. 526б, 531а, 539а; Б. Марковић, Јусӣинијанов закон, 75, 94; Законик ияара Сйефана Дущиана, Књ. IV, T. I, 281.

103 МСПЦ, Грујић бр. 127, лл. 526а, 527a, 541б, 544б; Б. Марковић, Јусииинијанов закон, 73, 79; Законик изара Сйефана Дущиана, Књ. IV, Т. I, 287, 292.

104 БМС, PP I 34, л. 1а. Иста грешка и у Ковиљском и Софијском рукопису.

105 МСПЦ, Грујић бр. 127, л. 526а.

106 Исто, лл. 272a, 2736, 473a, 4736. 


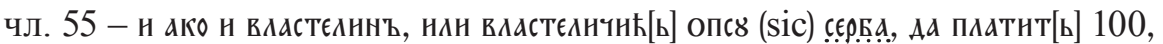

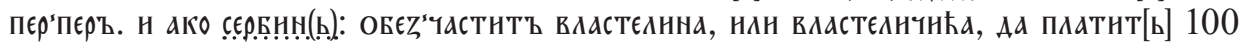
ПЕР^ПЕРЪ Н АА СЕ ОСМВАНТЬ; 107

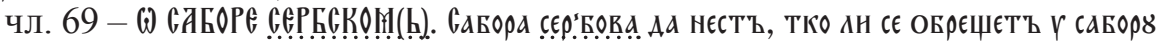

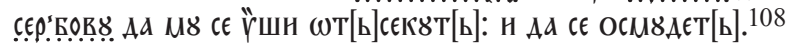

Међутим, у чл. 85 приближио се изворном значењу преиначивши „себра” у „сиромаха”, тј. припадника неповлашћених сталежа:

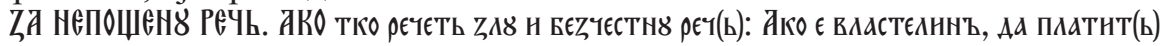

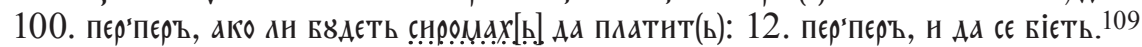

У чл. 94 и 98 протумачио је себра као сељака, земљорадника и употребио именицу пахорь (паор < нем. Bauer), ${ }^{110}$ раширену у говору Срба у Хабзбуршкој монархији. У чл. 98 ипак је дописао на маргини снромах:

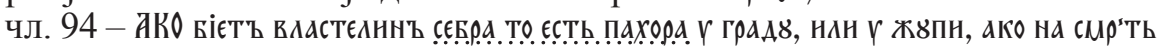

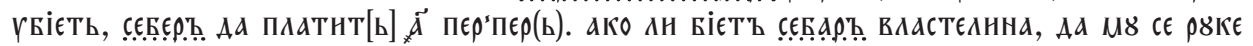

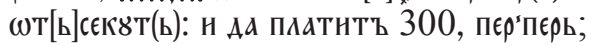

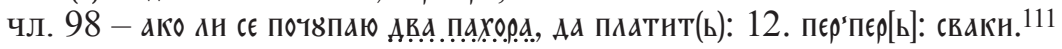

Рекло би се да је са истом намером Спиридон интервенисао у језику, настојећи да изменама у складу с народним говором учини прописе разумљивим. Могу се идентификовати бројни примери иновирања и то је једна од особених одлика Душанова законодавства у препису Спиридона Хоповца, којим се јасно одваја од свих других преписа:

\section{иновирани облици}

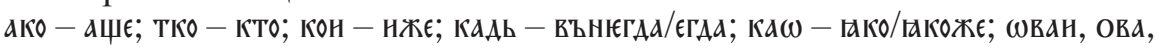

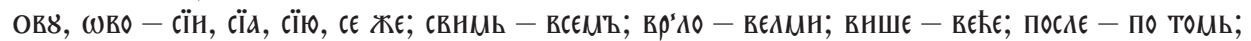

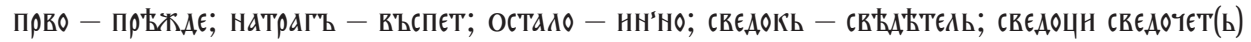

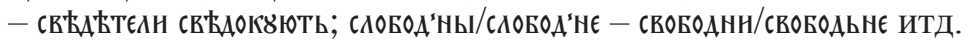

правописне иновације

Употреба слова /j/ спорадично, за умекшавање, иницијално и интервокалски:

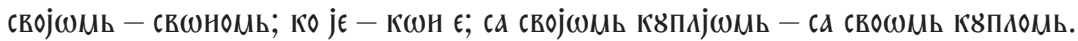

Употреба слова /y/, самостално и иницијално, при чему вь $>$ :

г свакомв град8 - въ всаком градъ (овде и иновирани падежни наставак); н ГСЕАНТ СЕ - н вьСЕАїТЬ СЕ ИТД.

лексичке иновације

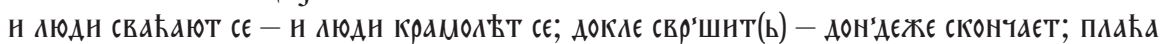

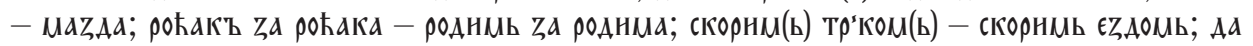

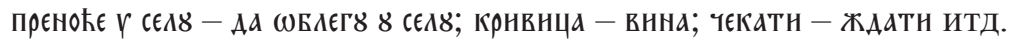

107 Исто, л. 539б.

108 Исто, л. 540а.

109 Исто, л. 542a.

110 Упор. В. Михајловић, Грађа за речник сйраних речи у йреgвуковском иеериоgу, II том (М-Ш), Нови Сад 1974, 449, 465.

111 МСПЦ, Грујић 127, лл. 542а, 5426. 
употреба турцизама и германизама из говорног језика

коншіамь, коншіє (< тур. komşu, konşu) - свсєАомь, свсєАд; дрєво коншінско - арьво

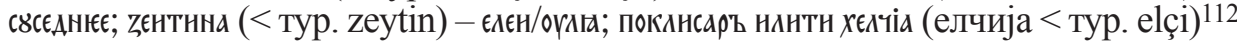
- покднсаръ; za пвстахїє н татє ( $\bar{y} y c \bar{u}-+$ - -ахија, према турцизмима типа сйахија,

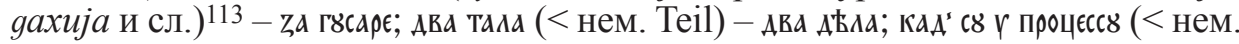
Prozess; лат. processus) два ревєлію (< нем. Rebellion; лат. rebellio) совнраєть на царя - нЖе чет૪ сьБнраєн на цара; пахора $(<$ нем. Bauer $)-$ сєвра.

\section{синтаксичке иновације}

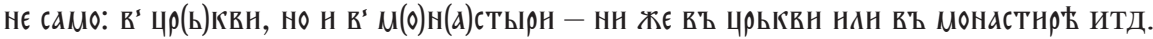

Без обзира на разлике између два преписа - Сан и Хоп - што без изузетка иду у заслуге редакторских интервенција преписивача Спиридона Јовановића, несумњиво је да је предложак с којег је преписао Душаново законодавство млађе редакције био управо Сан. О његовом настанку и судбини не зна се ништа до средине XIX века, када се појављује у својини Павла Карано-Твртковића, али нема података о томе како је и где доспео у његове руке. ${ }^{114}$ Чињеница да је са њега преписан текст сачуван у Сйирияонову зборнику говорио би у прилог томе да се, у зависности од тога где је Спиридон привео крају своју преписивачку работу, средином XVIII века налазио или у Пакрацу, на двору славонског епископа, или у манастиру Хопову. Истраживања нових извора за историју црквених библиотека у Хабзбуршкој монархији могла би довести до решења овог питања.

Иако Хоп не садржи елементе текста који већ нису познати, нити суштински доприноси напорима за реконструкцију његове историје, он се, ипак, по неким одликама издваја у наизглед монотоном низу преписа Душанова законодавства из XVIII века. То је једини познати пример да текстови Душанова законодавства нису примарни или једини у рукопису. Напротив, реч је о обимном зборнику разнородног састава, у који су ЗКЈ и ДЗ преписани на крају, без икакве везе, према пореклу и предмету, са осталим саставима преписаним међу истим корицама. То је зборник незваничног, приватног карактера, којим су, судећи према записима читалаца, монаси, али и световњаци задовољавали своју радозналост у различитим областима знања и образовања. Друга је особена одлика Хоп његов језик. Иако су елементи српскословенског и примесе рускословенског 115 присутни дуж читавог текста, изразита je, мада недоследно спроведена, Спиридонова намера да поједностави језички израз, да га приближи читаоцу елементима њему савременог народног говора. Таквом одликом може се, и то у још већој мери, похвалити само Режевићки препис, али са сасвим другог краја српског језичког простора.

112 Спиридон користи лик с почетним $x$; тако и на л. 254б: „татар(ь)скє хєлчіє”. Упор. В. Михајловић, н. д., 719.

113 Исто, 529.

114 Ђ. Бубало, „Историја и историографија рукописа”, Законик иара Се̄ефана Дущиана, Књ. IV, T. I, 28-31.

115 Илустрације ради наводим десетину примера из рускословенског: княzы, ся, нсквсєнъ,

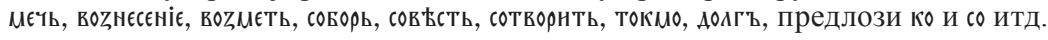




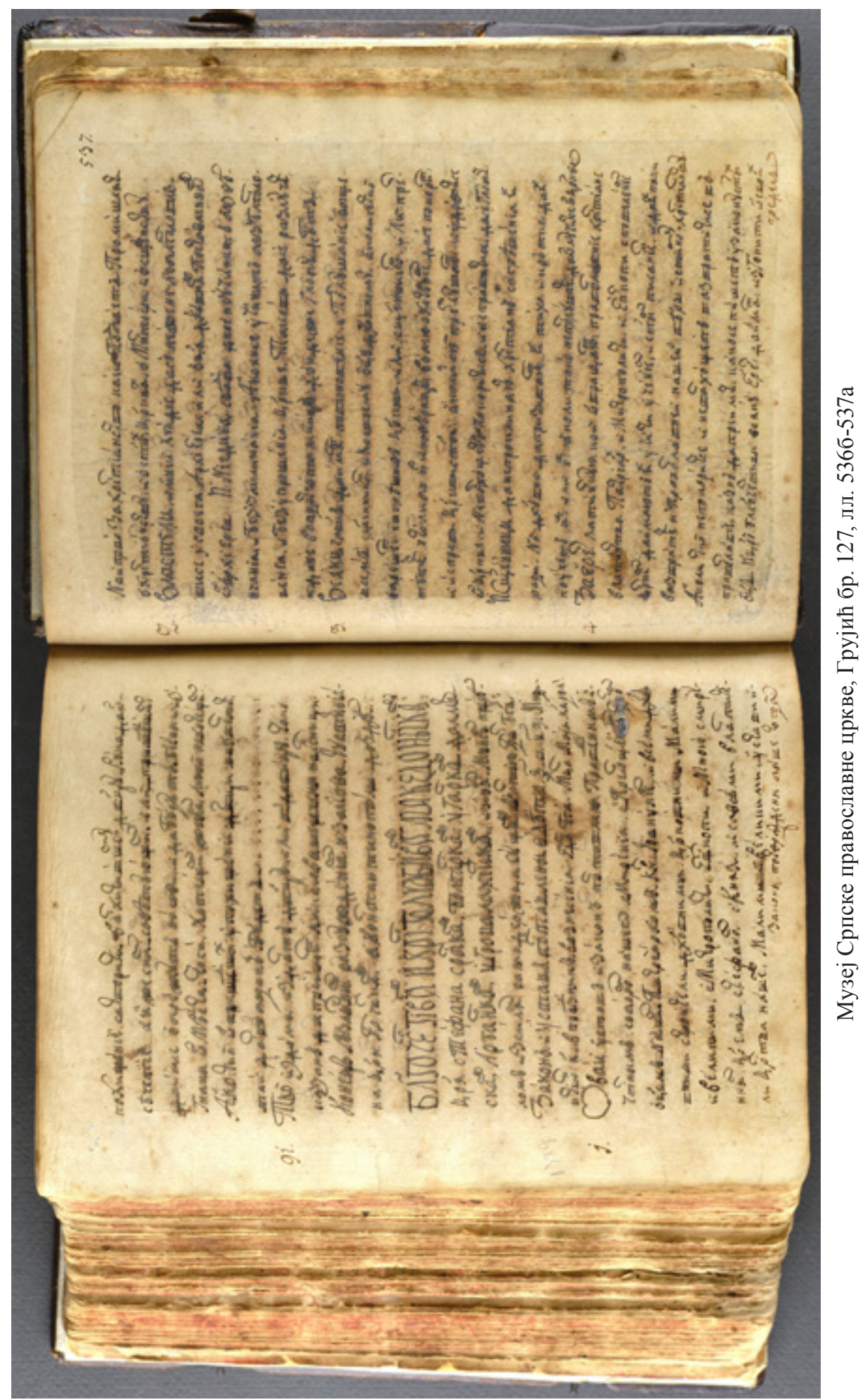


Најзад, излазак на светло дана новог, 27. преписа Душанова законика, после више од шест деценија прећутног мирења с веровањем да је број откривених рукописа тог правног споменика коначан, даје наду да ће се оптимистичне речи Николе Радојчића, цитиране на почетку овог прилога, поново потврдити новим открићима.

И овај препис ће, као што су и сви остали познати преписи Душанова законика, бити доступан за научна истраживања у едицији Извори срйской ирава, Одбора за изворе српског права Одељења друштвених наука САНУ.

ORIGINAL SCIENTIFIC PAPER

Prof. ĐORĐE BUBALO, PhD

University of Belgrade, Faculty of Philosophy

Čika Ljubina 18-20

Belgrade, Serbia

E-mail: djbubalo@f.bg.ac.rs

\section{AN (UN)KNOWN COPY OF DUŠAN'S CODE IN THE MUSEUM OF THE SERBIAN ORTHODOX CHURCH IN BELGRADE}

SUMMARY: The paper presents an overlooked copy of Dušan's legal code from the mid-18th century. It was discovered by Tihomir Ostojic in the library of the Hopovo monastery in 1906 while he was collecting material for his study about Dositej Obradović's stay at that monastery. The copy escaped the attention of researchers of Dušan's code for more than a century because there was no information about it in legal-historical literature. The codex includes over 500 leaves of diverse contents, with the younger redactions of Dušan's legislative documents appended at its end - the Code of Emperor Constantine Justinian and Dušan's Code. It was copied by Hopovo hieromonk Spiridon Jovanović around 1750, and it remained at that monastery, on the Fruška Gora mountains, until the beginning of the Second World War. Therefore, we have named it the "Hopovo" manuscript. It is now kept in the Museum of the Serbian Orthodox Church in Belgrade, in the Collection of Radoslav Grujić, under catalog number 127. Comparing it with other younger-redaction manuscripts of Dušan's legislation, we have established that the direct source from which Spiridon Jovanović copied Dušan's legislative documents was the so-called Sandić's (Stratimirović's) manuscript, created around 1724 and now in the Library of Matica Srpska in Novi Sad. The Hopovo copy does not bring any new content, but it is the only known example of Dušan's legislative documents not being the primary or only texts in a manuscript. Another distinctive characteristic of this copy is the proportionally large share of vernacular language and novel linguistic forms. With the rediscovery of this manuscript, the number of known copies of Dušan's Code has reached 27.

KEYWORDS: Dušan's Code, the Code of Emperor Constantine Justinian, the monastery of Hopovo, Spiridon Jovanović, Sandić's copy of Dušan's legislation, Tihomir Ostojić, the Museum of the Serbian Orthodox Church in Belgrade 